九州大学学術情報リポジトリ

Kyushu University Institutional Repository

\title{
Editorial
}

Saha, Bidyut Baran

Thermal Science and Engineering Division, International Institute for Carbon-Neutral Energy Research (WPI-I2CNER), Kyushu University: Professor and Principal Investigator | Kyushu University Program for Leading Graduate School, Green Asia Education Center : Adjunct Professor

Thu, Kyaw

Kyushu University Program for Leading Graduate School, Green Asia Education Center : Associate Professor

https://doi.org/10.5109/1936948

出版情報 : Evergreen. 4 (2/3)，pp. i i-i i i，2017-09. 九州大学グリーンアジア国際リーダー教育セン ター

バージョン:

権利関係: 


\section{C $\dot{\nabla} \wedge$}

\section{Editorial}

The vision of the Evergreen - Joint Journal of Novel Carbon Resource Sciences \& Green Asia Strategy is to publish scientific papers with high quality and be a part in making carbon-neutral society. The journey of Evergreen has reached Volume 4, Issue 2/3 edition since commencement. We are pleased to update that all the previously published articles are accessible in electronic version to the scientific community.

Evergreen has been a standout in publishing articles with significant contributions from multidisciplinary research areas such as polymer science [1], adsorption science and engineering [2-6], investigation of environmental-control and renewable energy-related systems [7-9], and social economics [10-12]. The current issue contains seven articles judiciously audited by expert reviewers. As always, this edition is well-balanced with articles from various research fields aiming to achieving a Green environment and society. We are convinced these articles exhibit deep scientific insights and knowledge.

We are grateful to the authors and our expert reviewers from all over the world in screening through the manuscripts. We gratefully acknowledge the support of the Editorial Board members and the Editorial Office Staffs, Mr. Masayoshi Makino and Ms. Mieko Inoue, who directed a great effort from the beginning till the publication.

\section{References}

1. Z. Xu, Y. Takahashi, and A. Takada, Evergreen, Jt. J. Nov. Carbon Resour. Sci. Green Asia Strateg. 1(1), 1 (2014).

2. H. W. B. Teo and A. Chakraborty, Evergreen, Jt. J. Nov. Carbon Resour. Sci. Green Asia Strateg. 2(2), 44 (2015).

3. A. Li, A. B. Ismail, K. Thu, M. W. Shahzad, K. C. Ng, and B. B. Saha, Evergreen, Jt. J. Nov. Carbon Resour. Sci. Green Asia Strateg. 1(2), 37 (2014).

4. K. Uddin, I. I. El-Sharkawy, and T. Miyazaki, Evergreen, Jt. J. Nov. Carbon Resour. Sci. Green Asia Strateg. 1(1), 25 (2014).

5. H. Yang and A. Harata, Evergreen, Jt. J. Nov. Carbon Resour. Sci. Green Asia Strateg. 2(2), 1 (2015).

6. J. Miyawaki, J. Yeh, H.-S. Kil, J.-K. Lee, K. Nakabayashi, I. Mochida, and S.-H. Yoon, Evergreen, Jt. J. Nov. Carbon Resour. Sci. Green Asia Strateg. 3(2), 17 (2016).

7. Y.-D. Kim, K. Thu, and K. C. Ng, Evergreen, Jt. J. Nov. Carbon Resour. Sci. Green Asia Strateg. 2(2), 50 (2015).

8. C. Li and K. Ito, Evergreen, Jt. J. Nov. Carbon Resour. Sci. Green Asia Strateg. 1(1), 12 (2014).

9. K. T. Zingre, X. Yang, and M. P. Wan, Evergreen, Jt. J. Nov. Carbon Resour. Sci. Green Asia Strateg. 2(2), 34 (2015).

10. M. K. Barai and B. B. Saha, Evergreen, Jt. J. Nov. Carbon Resour. Sci. Green Asia Strateg. 2(1), 49 (2015).

11. T. Sato, Evergreen, Jt. J. Nov. Carbon Resour. Sci. Green Asia Strateg. 3(2), 25 (2016).

12. K. Moroga, A. Nagata, Y. Kuriyama, T. Kobayashi, and K. Hasegawa, Evergreen, Jt. J. Nov. Carbon Resour. Sci. Green Asia Strateg. 2(2), 14 (2015). 
Bidyut Baran Saha \& Kyaw Thu

Editor-in-Chiefs

Evergreen - Joint Journal of Novel Carbon Resource Sciences \& Green Asia Strategy

Bidyut Baran Saha, Ph.D.

Professor and Principal Investigator

Thermal Science and Engineering Division

International Institute for Carbon-Neutral Energy Research (WPI-I'CNER)

Kyushu University

744 Motooka, Nishi-ku, Fukuoka-shi, Fukuoka 819-0395, Japan

Tel and Fax: +81-92-802-6722

E-mail: saha.baran.bidyut.213@m.kyushu-u.ac.jp

\section{Adjunct Professor}

Kyushu University Program for Leading Graduate School, Green Asia Education Center

Kasuga-koen 6-1, Kasuga-shi, Fukuoka 816-8580, Japan

Tel: +81-92-583-7903, Fax: +81-92-583-8909

E-mail: sahabb@gmail.com

URL: http://www.cm.kyushu-u.ac.jp/dv10/Koyama_lab/pdf/Prof.Saha.pdf

http://www.cm.kyushu-u.ac.jp/dv10/Koyama_lab/pdf/Research_Interest_Prof.Saha.pdf

Kyaw Thu, Ph.D.

Associate Professor

Kyushu University Program for Leading Graduate School, Green Asia Education Center

Kasuga-koen 6-1, Kasuga-shi, Fukuoka 816-8580, Japan

Tel: +81-92-583-7903, Fax: +81-92-583-8909

E-mail: kyaw.thu.813@m.kyushu-u.ac.jp 